\title{
Geomorphic Threshold for Gully Initiation in Different Geographical Environments of Wanjoga River Catchment, Tana Basin, Kenya
}

\author{
Cecilia Ireri, George 0. Krhoda, Mikalitsa S. Mukhovi \\ Department of Geography and Environmental Studies, University of Nairobi, Nairobi, Kenya \\ Email: ceciliaireri@gmail.com
}

How to cite this paper: Ireri, C., Krhoda, G.O. and Mukhovi, M.S. (2021) Geomorphic Threshold for Gully Initiation in Different Geographical Environments of Wanjoga River Catchment, Tana Basin, Kenya. Journal of Environmental Protection, 12, 547-560.

https://doi.org/10.4236/jep.2021.128034

Received: July 2, 2021

Accepted: August 20, 2021

Published: August 23, 2021

Copyright $\odot 2021$ by author(s) and Scientific Research Publishing Inc. This work is licensed under the Creative Commons Attribution International License (CC BY 4.0).

http://creativecommons.org/licenses/by/4.0/

\begin{abstract}
Gullies in semi-arid region are important in landscape modification, degradation and increased overland flow affecting geomorphic thresholds of an area. Gullies generate about $95 \%$ of global sediment load, important in landscape modification, degradation and increased overland flow in semi-arid regions, but little is known on geomorphic factors that increase ecological fragility increasing gully initiation. To address the problem, landscape regions of accelerated geomorphic processes must be determined. The study aimed to establish topographical thresholds and geomorphic factors which increase landscape fragility in gully head positions in different geographical regions. Gully heads were analyzed by detailed field surveys from $10 \mathrm{~m}$ up and down-slope position. Drainage area contributing to gully was demarcated from the point overland flow was assumed to reach the gully head based on water visible flow-lines while gully head slopes were determined by use of clinometers. Gully threshold concept was applied to identify the critical slope $(S)$ and drainage area $(A)$, using appropriate $S-A$ relation $\left(S=a A^{b}\right)$ and verified using ANOVA. The empirical $S-A$ threshold relation $S=0.383 A^{-0.397}, R^{2}=$ 0.0321 (upper-segment), $S=0.174 A^{-0.032}, R^{2}=0.498$ (mid-segment), $S=$ $0.23 A^{-0.020}, R^{2}=0.088$ (lower segment), represented approximate critical slope-drainage area for gully initiation and regions of dominant geomorphic processes, above which gully initiation was likely to occur. Negative $b$ values represent an areas more dominated by overland flow over sub-surface processes. Coefficient of correlation multiple $R=0.7055$ (70.55\%) Mid-segment indicated strong relation slope-drainage area for gully initiation. ANOVA analysis $\mathrm{p}=0.01,0.004$ and 0.4498 for upper, mid and lower segment respectively revealed stronger relation between independent and dependent variables. $\mathrm{p}>$ 0.05 indicated regions influenced by more factors than slope and drainage area. Thus, slope-drainage threshold relation line can be applied in the
\end{abstract}


semi-arid environments to locate vulnerable sites of dominant geomorphic processes which should be checked for gully conservation.

\section{Keywords}

Gully Initiation, Geomorphic Threshold, Semi-Arid

\section{Introduction}

Gully development is associated with the initial incision of microscopic hollows by running water, influenced by a wide range of geomorphological factors including: morphological conditions and geomorphological factors [1] [2] [3] [4]. Geomorphological factors affect surface and sub-surface overland flow, a process focused as a threshold, bringing instability in a landscape. Instability on landscapes occurs where additional sediment transport capacity generated by flow convergence in a proto-hollow, exceeds the sediment brought in by the flow convergence [5] Instability creates conditions under which very small proto-hollows grow into macroscopic gullies [6]. These conditions occur where rainfall rate exceeds the infiltration capacity of soil; water flows in the direction of the slope. This kind of overland flow depends mainly on the surface characteristics that control morphology, land cover and soil type [7]. Surface characteristics variations, intrinsic and extrinsic factors (rainfall, soil characteristics, terrain and land cover), bring about variations in critical values of slope and catchment area required in gully initiation [5].

Extrinsic geomorphic factors in a catchment determine gully initiation rate [8], while gully topographic factors determine rate of gully progression. Initiation stage of a gully is often the most critical; since once gullies have initiated and gully network systems are formed, they are difficult and costly to eradicate [9]. Thus predicting the incision points for gullies in various environments is an important step towards predicting their development rates.

Numerous studies [5] [8]-[14] have established the topographical threshold for gully erosion in relation to geomorphic factors related to land use/land cover factors (forested areas, rangelands, pastures and cropland). A geomorphic threshold occurs due to instability in a landform system coursed by exceeding changes in intrinsic factors (slope, soil characteristics) or by a progressive change of an external variable surrounding a gully; drainage area, rainfall variability, land use/land cover [10] [13], which in turn influences velocity of concentrate flow. Further, volume and velocity of concentrated flow are controlled by slope characteristics, such as contributing drainage area, slope length and slope steepness [5] [8] [11] [12], which further determine rate of gully initiation and progression.

For gully initiation to occur in a catchment area, a critical slope must be exceeded; or for gully initiation to occur in a given slope, a critical catchment area 
must have been exceeded [15]. For instance, creation of paths and roads may lead to reduction or expansion of drainage area, due to changes in direction of overland flow brought about by artificial flow on paths and roads. Channelized erosion created by paths and roads often requires lower critical slope for gullying initiation [1] [16]. Thus, for effective gully rehabilitation and prevention, critical values for slope and drainage area must be determined in different geographical environments which determine differences in geomorphological factors across landscapes. Such information in gullied areas of semi-arid regions is very scarce. Therefore, the present study set out to determine geomorphic thresholds for gully head development in a semi-arid environment of different geographical regions of varied slope angle, soil lithotypes, land cover and rainfall variability.

\section{Materials and Methods}

\subsection{Study Area}

The Wanjoga River catchment (Figure 1) is a semi-arid region covering about $200.54 \mathrm{KM}^{2}$, a sub-catchment of Tana Basin, Embu County. The basin is located at latitude $0^{\circ} 34^{\prime} 0.48^{\prime \prime}$ south and longitude $37^{\circ} 42^{\prime} 33.88^{\prime \prime}$. Geologically, the area falls under four groups, the Archaean rocks of the Neoproterozoic units including; the Embu Series, the Tertiary volcanic and basement system of the recent age. The highest peaks of the area include; Kiang'ombe ranges $(1700 \mathrm{~m})$ and the

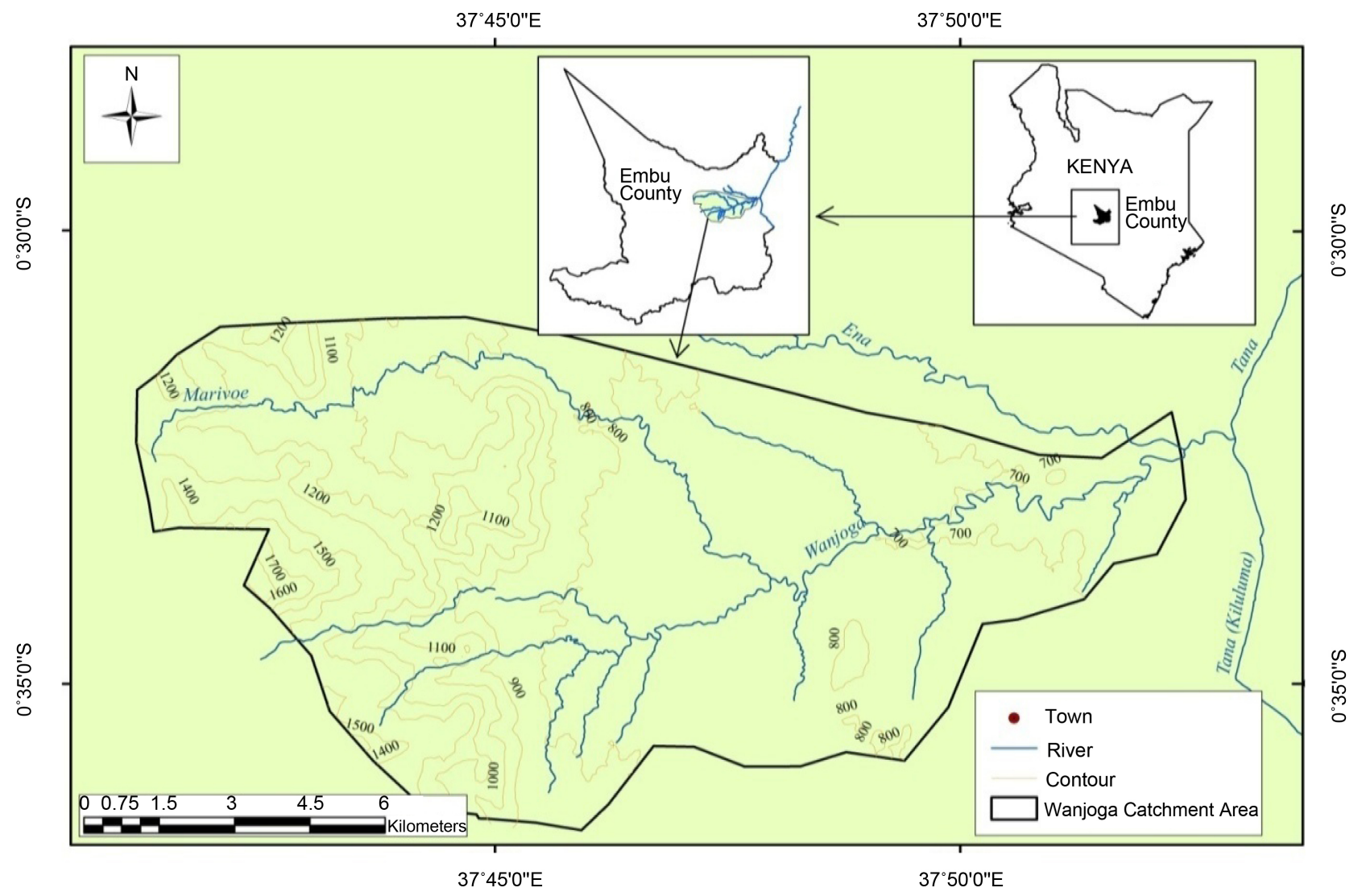

Figure 1. Wanjoga river catchment. 
Mumoni Mountains (1400 m), considered as the high-level peneplain of supposed end-Cretaceous age [17]. These rocky outcrops are most prominent geological features forming the main outcrop blocks of resistant granitoid gneiss. The impermeable granitoid gneisses resist weathering, while the intervening valleys are composed of less resistant and more permeable biotite gneiss, magatitic gneisses, and banded gneisses [18]. Nature of rocks determines soil types of an area which form an important variable of the current study.

The soils of the region are deep to shallow with the top of Kiang'ombe hill of shallow sandy clay loam to clay (lithosols) to clay loam to clay (cambisols), with weatherable materials since granitoid gneisses resist weathering [18] [19]. Lithosols are brownish to reddish with clay soils exhibiting dark red to light grayish character with high sand content and weatherable materials making them excessively drained [19]. At the foot slopes towards the adjoining valleys soils are arenosols (loam sandy to loam clay), which are deep and well drained. In lowland areas near the Tana River soils are stony loam (sandy clay to loam) cambisols which are well drained.

Physiographicaly, the area has two units; Mountains regions of the area and the river valleys, with elevation ranging from $500 \mathrm{~m}-700 \mathrm{~m}$. The highest peak is Kiang'ombe hill at $1700 \mathrm{~m}$ which is the chief mountainous region. Separating these mountains regions are broad valleys through which rivers such as, Wanjoga and Enacut their course. The lowest altitude is about $500 \mathrm{~m}$ on the Tana River valley which is the main and perennial river where all other rivers from Kiang'ombe hill drain [18]. Wanjoga River has a limited flow in the upper reaches during the dry season while many other rivers are seasonal. The topography nearer the Tana, is fairly rugged with hills, valleys and features such as fault lines, folds and dykes all affecting the direction of movement of surface and underground water [18]. This study attempted to draw relationship between variations in topography in the area and gully development over time. Rainfall is very unreliable and decreases in southwards and eastwards direction averaging 900 $\mathrm{mm}-550 \mathrm{~mm}$ per annum [20]. 60\% of the total rainfall is received in longer and more reliable season (March-May), while 40\% falls between October and December which is shorter and less reliable season [19]. The study seeks to establish effect of rainfall variability in gully initiation and growth over time.

Study area has five major land cover; Forest cover (thick rain forest and wooded vegetation), vegetation cover (thickets and bushes), cultivated land, bare land (non-vegetated land, built-up area, road surfaces, rocky outcrops), and water surface (permanent and seasonal rivers, swampy areas, water pans). Over $80 \%$ of the people practice crop farming (cassava, maize, beans, cowpeas, pigeon peas and millet), with livestock production more preferred to the southern and eastern regions [21] [22]. Erratic nature of rainfall coupled with poor farming practices tends to increase overland flow which accelerates gully erosion. The study seeks to establish how the nature of land cover/land use in the area affects gully development. 


\subsection{Research Methods}

\subsubsection{Sources of Data}

Primary data obtained from extensive and detailed field surveys along gullies and gullied areas was used to establish the threshold for gully erosion in the study area. Drainage area contributing to the gully was measured by demarcating the area from which overland flow was assumed to reach the channel cross-section at the gully head position. Areas contributing surface runoff to gully heads were determined by use of GPS based on water visible flow-lines, and measured using a 50-meter-long surveyor's measuring tape. Slopes at gully heads were determined in the field by use of clinometers. Geomorphic factors nearest to the gully head were defined from the point $10 \mathrm{~m}$ up-slope and down-slope. Gully head positions were recorded by use of Garmin GPS mapper 62s receiver for the 31 most active gullied areas from December 2020. Gully head GPS positions were imported into ArcGIS and used to digitize topographic parameters and to calculate drainage areas to establish critical slope and drainage area for gully initiation across different landscapes. Soil samples were picked from the gully head position for analysis to depict the role of lithotypes on gully initiation at gully head positions.

\subsubsection{Data Analysis}

By use of 31 gully heads, threshold was modeled using topographic threshold of the contributing area $(A)$ and gradient $(S)$ using an appropriate $S-A$ relation for the environment to determine risk of having gully initiation on slope. The relationship is described by the power function, using equation [23]. A critical $S-$ $A$ relationship that may be used to identify the position of gully initiation can be expressed as:

$$
S=a A^{b}
$$

where;

$S$ is the local slope $(\mathrm{m} / \mathrm{m}), A$ is the drainage area (ha) up-slope of the head cut, $a$ is a coefficient and $b$ is an exponent. Both " $a$ " and " $b$ " take different values under various environmental conditions. The values of " $a$ " and " $b$ " are derived from log-log scale plot of " $S$ " versus " $A$ ". Information obtained was used to determine distance of surface overland flow surface required for gully initiation at specific slope angle. Geomorphological factors around the gully head including; soil type, rainfall variability and land cover were also analyzed since the exponent value is dependent on this factors.

To judge the statistical relationship between dependent and independent variables, analysis of variance (ANOVA) tests were performed by use of the regression coefficients.

$$
y=b_{0}-b_{1} x
$$

where

$$
\begin{aligned}
& y \text {-Slope; } \\
& x \text {-Area; }
\end{aligned}
$$


$b_{0}$ - Regression intercept;

$b_{1}$-Coefficient of area.

\section{Results and Discussions}

Understanding topography threshold in a local slope is key in controlling gully erosion rates. To effectively analyze threshold for gully initiation, 31 field datasets on gullied areas were collected in different geographical regions of the study areas: 11 in the upper segment (slopes $\left.>20^{\circ}\right), 14$ in mid-segment $\left(11^{\circ}-20^{\circ}\right)$ and 6 in the lower segments (slopes $<11^{\circ}$ ), and assessed for resistance to gully initiation. The 31 gully heads for the most active gully channels were analyzed to determine soil slope, drainage area and geomorphic factors that contributes surface runoff to the initiation points.

\subsection{Gully Head Erosion Survey}

The summary statistics on all the 31 gully heads sites in Wanjoga river catchment is shown in Table 1. Gullied sites located at upper segment require smallest drainage area for gully initiation $(0.064 \mathrm{ha})$, mid-segment region $(0.84 \mathrm{ha})$, while gentle slopes $\left(<10^{\circ}\right)$ regions require the largest drainage area for gully initiation (2.59 ha).

The average gully head width at upper segment was reported at $1.3 \mathrm{~m}, 1.5 \mathrm{~m}$ for the mid-segment and $2.3 \mathrm{~m}$ for the lower segments. Contrary, the lower segment has the lowest average depth at $0.3 \mathrm{~m}$ compared to $0.6 \mathrm{~m}$ depth for upper segment and an average at $0.8 \mathrm{~m}$ for the mid-segment region. Average depth and

Table 1. Characteristic of major gullied areas.

\begin{tabular}{|c|c|c|c|}
\hline Characteristics (units) & $\begin{array}{l}\text { Upper slope } \\
\qquad(\mathrm{n}=11)\end{array}$ & $\begin{array}{l}\text { Mid-slope } \\
(\mathrm{n}=14)\end{array}$ & $\begin{array}{l}\text { Lower slope } \\
\qquad(n=6)\end{array}$ \\
\hline Altitude (masl) & $1200-1800 \mathrm{~m}$ & $900-1200 \mathrm{~m}$ & $600-900 m$ \\
\hline Average slope ${ }^{\circ}$ & $20.6^{\circ}$ & $8.4^{\circ}$ & $4^{\circ}$ \\
\hline $\begin{array}{l}\text { Mean gully heads slope } \\
\qquad(\mathrm{m} / \mathrm{m})\end{array}$ & 0.36 & 0.15 & 0.067 \\
\hline Area $\left(\mathrm{km}^{2}\right)$ & 36.1 & 112.3 & 52.1 \\
\hline Main lithotype & $\begin{array}{l}\text { Combisols } \\
\text { (clay > 51\%) }\end{array}$ & $\begin{array}{l}\text { Combisols } \\
\text { (clay }>45 \%)\end{array}$ & Arenosols \\
\hline Main land cover & $\begin{array}{l}\text { Forest, vegetated, } \\
\text { cultivated }\end{array}$ & $\begin{array}{l}\text { Vegetated, } \\
\text { bare land }\end{array}$ & $\begin{array}{c}\text { Cultivation, } \\
\text { vegetated, bare land }\end{array}$ \\
\hline $\begin{array}{c}\text { Mean width at gully } \\
\text { head }(\mathrm{m})\end{array}$ & 1.3 & 1.5 & 2.3 \\
\hline $\begin{array}{c}\text { Mean depth at gully } \\
\text { head }(\mathrm{m})\end{array}$ & 0.6 & 0.8 & 0.3 \\
\hline $\begin{array}{l}\text { Average gullied volume } \\
\text { per gully } \mathrm{m}^{3}\end{array}$ & 455 & 1554 & 1740 \\
\hline $\begin{array}{l}\text { Average drainage areas } \\
\text { (ha) }\end{array}$ & 0.064 & 0.84 & 2.59 \\
\hline
\end{tabular}


width determined nature of gullied volume, with regions recording depth and width $<0.5 \mathrm{~m}$ such as upper segment, estimating volume at $455 \mathrm{~m}^{3}$. Regions of higher gully parameters $(>0.5 \mathrm{~m})$, recorded higher volume at $1554 \mathrm{~m}^{3}$ and 1740 $\mathrm{m}^{3}$ for mid and lower segments respectively. The values suggest that presence of steep slopes may facilitate faster movement of surface material, thus, quicker gully initiation which increase gully occurrence. Gullies in upper segment required minimum drainage area $(0.064 \mathrm{ha})$ at steeper slope $(0.36 \mathrm{~m} / \mathrm{m})$, for gully initiation compared to lower segment which require a maximum drainage area of 2.59 ha at a gentler slope of $0.067 \mathrm{~m} / \mathrm{m}$. The results compare with those of Sun et al., (2013) where estimated slopes of $0.035-0.088 \mathrm{~m} / \mathrm{m}$ are considered as the threshold for gully initiation for lower loam slopes of agricultural lands in European countries.

\subsection{Effects of Slope and Drainage Area on the Gully Development}

Based on computed slopes $(S)$ and drainage areas $(A)$ relations, an empirical power regression was developed which can be used as value for threshold to gully initiation in the study region and reported in Table 2. For the three geographical segment, slopes above gully heads are positively correlated $R^{2}=0.0321$ and $\mathrm{p}=0.59$ for upper segment, $R^{2}=0.498, \mathrm{p}=0.005$ for mid-segment and $R^{2}=$ $0.088, \mathrm{p}=0.04$ for the lower segments. For the upper segment, the coefficient of determination $R^{2}=0.032$, indicates that $3.2 \%$ of changes in slope is attributed to the change in drainage area according to the linear regression model with coefficient of correlation multiple $R=0.179(18 \%)$ indicating a weak correlation between independent and dependent variables. Thus, $3.2 \%$ variation in gully development is explained by variation in slope and drainage area. A low $R^{2}$ value (3.2\%) indicates that other than slope and drainage area, varied geomorphic factors (soil characteristics, rainfall characteristics, land cover) plays a major role in gully initiation.

In the lower segment, the coefficient of determination $R^{2}=0.498$, indicates $14.98 \%$ changes in slope is attributed to the change in area according to the linear regression model. Thus, $14.98 \%$ variation in gully development is explained by variation in slope and drainage area for gully initiation. This implies, a small percentage of gully formation is determined by slope and drainage area factors only, but other variables such as land use, rainfall and soils, plays a major role in gully formation. In the mid-segment, the coefficient of correlation multiple $R=$

Table 2. Regression statistic output in geographical regions.

\begin{tabular}{cccc}
\hline Regression statistic & Upper segment & Mid-segment & Lower segment \\
\hline Multiple R & 0.179106 & 0.705522 & 0.385936 \\
R Square $\left(R^{2}\right)$ & 0.032079 & 0.497761 & 0.148946 \\
Adjusted R Square & -0.07547 & 0.455908 & -0.06382 \\
Standard Error & 0.154365 & 0.024722 & 0.032822 \\
Observations & 11 & 14 & 6 \\
\hline
\end{tabular}


$0.7055(70.55 \%)$, an indication of a strong correlation between slope and drainage area in gully initiation. Thus, slope and drainage is an important factor influencing gully initiation to a larger extent.

\subsection{Slope-Drainage Area Threshold for Gully Head Initiation}

Figures 2-4 show the relationship between slopes of the terrain against drainage area to gather with line of best fit (linear regression line). Visual observation on upper segment reveals that the relationship between slope and drainage area is inverse, therefore, slope reduces with increase in drainage area. Regions of steeper slopes (slope $>0.4 \mathrm{~m} / \mathrm{m}$ ), gully initiation requires minimum drainage area to occur $(\mathrm{A}<0.05 \mathrm{ha})$. Contrary, regions of gentle slope require a large drainage (A $>0.15 \mathrm{ha}$ ) for effective concentrate flow, for gully initiation. The direction of correlation can be seen from the slope coefficient of $\mathrm{X}={ }^{-0} 0.314$ in the regression equation an indication of a negative correlation between slope and area (Figure 2).

In the mid-segment region, visual interpretation between slopes of the gully head and drainage area (Linear regression line), indicates that slope reduces with the increase in drainage area. Thus, there is a negative slope meaning, the relationship between slope and area is inverse. Thus, as drainage area increases, slopes required for gully initiation decreases with minimum slope at $0.1 \mathrm{~m} / \mathrm{m}$ for 1.7 ha critical drainage area. The direction of correlation can be seen from the slope (coefficient of $\mathrm{x}$ ) in the regression equation $\mathrm{X}=-0.0323$ indicating a negative correlation between slope and area (Figure 3).

In the lower segment, the relationship between slopes of gully head terrain drainage area in the line of best fit (Linear regression line), displays an inverse relationship, therefore, slope reduces with increase in drainage area. Thus, as drainage area increases, critical slopes for gully initiation decreases with minimum slope at $<0.1 \mathrm{~m} / \mathrm{m}$ for area $>2$ ha critical drainage area. The direction of correlation can be seen from the slope (coefficient of $\mathrm{x}$ ) $\mathrm{X}=-0.0203$ in the regression equation, an indication of a negative correlation between slope and

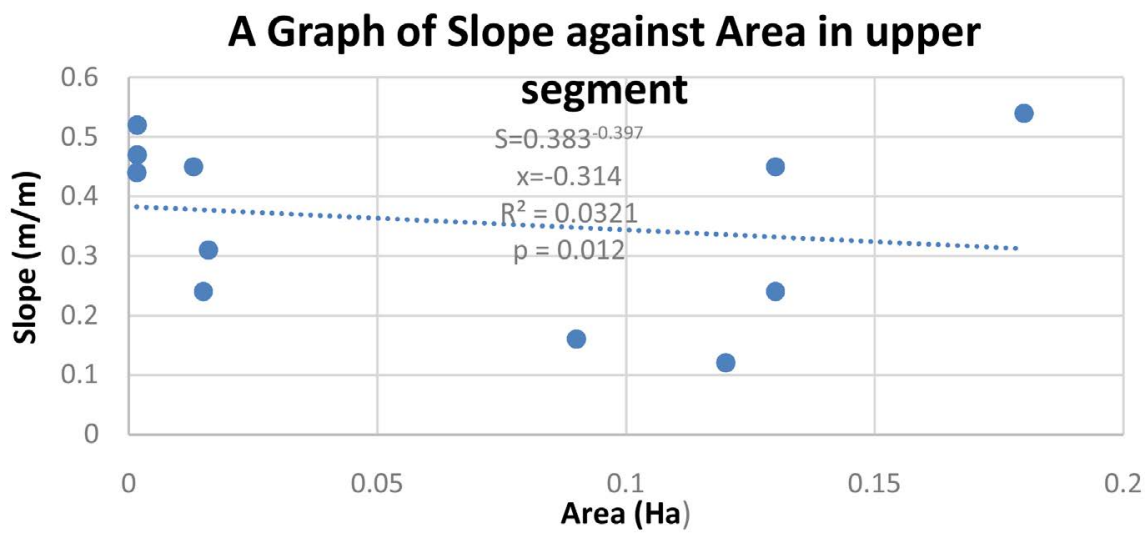

Figure 2. Relationship between slope gradient $(S)$ at the gully head and upslope drainage area $(A)$ in upper segment. 


\section{A Graph of Slope against Area in mid-segment}

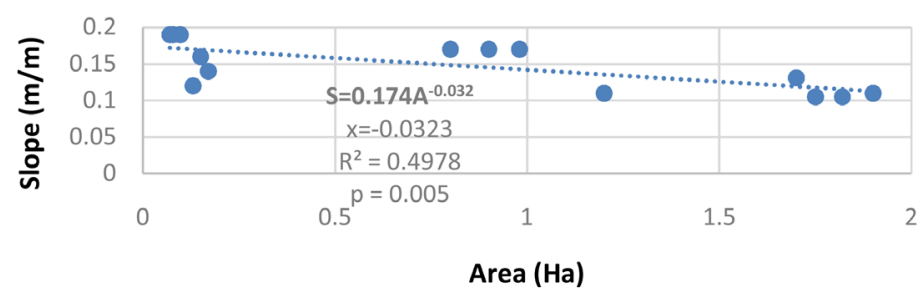

Figure 3. Relationship between slope gradient $(S)$ at the gully head and upslope drainage area in mid-slope segment.

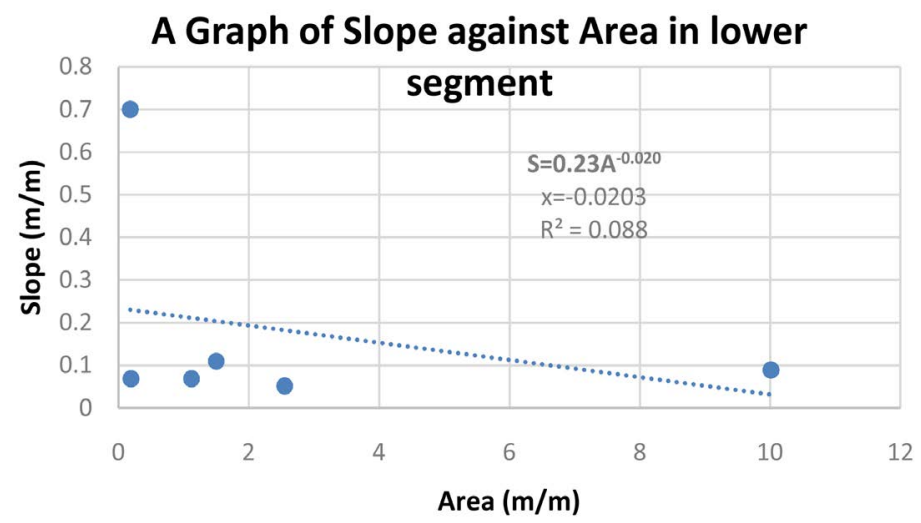

Figure 4. Relationship between slope gradient $(S)$ at the gully head and upslope drainage area in lower slope segments.

drainage area (Figure 4).

The empirical straight line ( $\left.S=0.383 A^{-0.397}\right)$, with $R^{2}$ of 0.0321 for upper segment, $\left(S=0.174 A^{-0.032}\right)$, with $R^{2}$ of 0.498 for mid-segment and $\left(S=0.23 A^{-0.020}\right)$, with $R^{2}$ value of 0.088 , for the lower segment, represents an approximation critical slope - drainage area threshold relationship for gully initiation (Figures 2-4). Any area gullied or un-gullied lying above these critical lines in specific regions is much prone to gully erosion and most dominated by geomorphic processes which increase gully initiation in a semi-arid region such as Wanjoga River catchment.

Comparing the three slope-area threshold graphs, the upper section requires higher topographical threshold for gully initiation at $b=-0.397$ compared to mid-segment $b=-0.032$ and lowest at lower segment at $b=-0.020$, with negative $b$ values $(<0.2)$, considered to identify areas more dominated by overland flow over sub-surface processes [5] [24]. [23], concluded, slope/drainage area thresholds at approximately -0.4 occur in areas with a wide variety of environments such as land uses/land cover and climate zones. Thus observed negative $b$ values at Wanjoga river catchment indicate a region impacted by more factors than slope and drainage area, including geomorphic factors which increase common channel initiation mechanisms including; concentrated overland flow, shallow landsliding and slumping. Differences in threshold levels can therefore be attributed to differences in these environmental factors in different geo- 
graphical regions, such as a rainfall variability, land cover and soil lithotype which bring differences in erosion resistance of the soils (Table 3). Lower critical threshold values for gully initiation at lower segment compared to upper segment can best be explained by the relatively high resistance to erosion due to lower slope angle and nature of soil lithotypes (arenosols) with more land under cultivation with different conservation measures employed by farmers in their farms.

In all soil samples collected, the upper segment has more combisols (clay 51\%) with weatherable materials compared to lower segment with arenosols. Soils with higher content of clay; combisols present at upper segment tend to form cracks during dry periods which act as cavities through which concentrate overland flow occur (Figure 5). Steady increase in cavities increase gully frequency over time, with $50 \%$ of gullies occurring in this region. The more the frequency the gullies, the greater the number of gullies per unit area.

In lower and mid segment regions soils lithotypes with stony weatherable materials possibly triggers sliding over the bedrock in the concentrated flow zone. Presence of weatherable materials triggers accelerated concentrated flow on the lower section of the channel which triggers slumping and failures which increase overall gully volume.

Table 3. Geomorphological differentiation across geographical regions.

\begin{tabular}{ccccc}
\hline $\begin{array}{c}\text { Geographical } \\
\text { segment }\end{array}$ & Soil type & Soil property & Vegetation cover & Gully \% \\
\hline Upper segment & $\begin{array}{c}\text { Combisols } \\
(\text { clay }>51 \%)\end{array}$ & Clay loam to clay. & Forested & 50 \\
Mid-segment & $\begin{array}{c}\text { Combisols } \\
(\text { clay }>\text { 45\%) }\end{array}$ & Clay sandy to clay & Vegetated & 37.9 \\
Lower segment & Arenosols & $\begin{array}{c}\text { Loam sandy to } \\
\text { loam clay }\end{array}$ & Cultivated & 12.1 \\
\hline
\end{tabular}

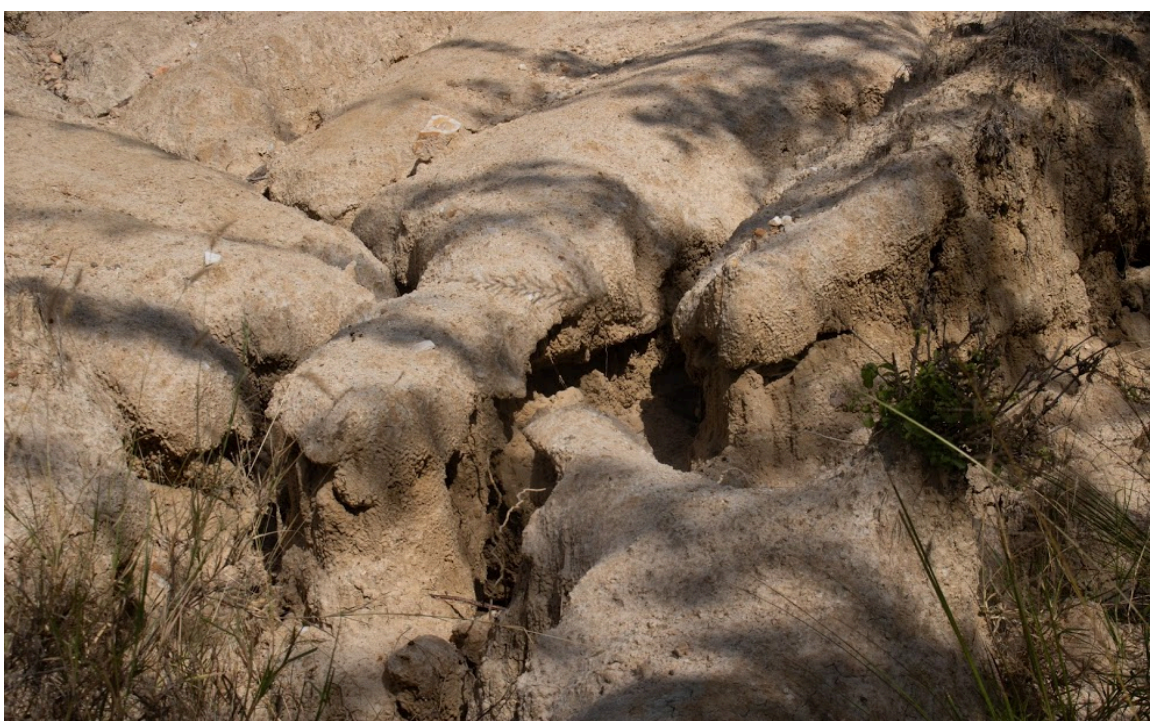

Figure 5. Increased channelization on cracked combisols. 


\subsection{ANOVA Predictor for Gully Development}

This relationship was further emphasized by use of Analysis of variance (ANOVA), to test the differences in slope and drainage areas between the gullied areas across the landscape at significance level $p=0.05(5 \%)$. The results displayed in Table 4 predicted $\mathrm{p}=0.01$ at upper segment reveals that slope and drainage area are statistically significant in predicting gully initiation points. Thus, gully initiation in the upper segment requires steeper slopes for gully development.

For the mid-segment region, significance value $\mathrm{p}=0.004$ from ANOVA predict a strong relation, thus, slope and drainage area are statistically significant in predicting gully initiation. At the lower segment, observed $\mathrm{p}=0.4498$, higher than significance level of 0.05 predicting that slope and drainage area statistically not significant in predicting gully initiation points in Wanjoga river catchment. Therefore, the study upholds the null hypothesis implying that, there is no significant linear relationship between independent and dependent variables at 5\% significance level. Thus, though drainage area and slope gradient influences gully initiation, other geomorphic factors play a significance role since they influence overland flow dynamics. Most significantly, discharge from roads requires lowers critical slope for a given drainage area for initiation. For such gullies, gully initiation starts only a few meters from the road, as observed on four main gullied areas on road side, with drainage area ranging from 0.0017 ha at $0.47 \mathrm{~m} / \mathrm{m}$ slope in Kiang'ombe while lower segment regions such as Ngose represent maximum drainage area for gully initiation at 0.19 ha and minimum slope at $0.069 \mathrm{~m} / \mathrm{m}$ slope for head initiation and progression (Table 5).

Despite low drainage areas for gully initiation, road side gullies exhibit longer characteristic ranging from $800 \mathrm{~m}$ at Kathera to $1660 \mathrm{~m}$ at Iriaitune in lower segment, though the area has a very gentle initiation slope of $0.019 \mathrm{~m} / \mathrm{m}$. This is consistent with studies of [1] which concludes that, lower critical slope and

Table 4. ANOVA for predictor variables.

\begin{tabular}{cccccc}
\hline Upper slope & $d f$ & SS & $M S$ & $F$ & Significance $F$ \\
\hline Regression & 1 & 0.007108 & 0.007108 & 0.298278 & 0.010024 \\
Residual & 9 & 0.214456 & 0.023828 & & \\
Total & 10 & 0.221564 & & & \\
\hline Mid segment & $d f$ & SS & MS & $F$ & Significance $F$ \\
\hline Regression & 1 & 0.007268 & 0.007268 & 11.89301 & 0.004817 \\
Residual & 12 & 0.007334 & 0.000611 & & \\
Total & 13 & 0.014602 & & & \\
\hline Lower segment & $d f$ & $S S$ & $M S$ & $F$ & Significance $F$ \\
\hline Regression & 1 & 0.000754 & 0.000754 & 0.700057 & 0.449838 \\
Residual & 4 & 0.004309 & 0.001077 & & \\
Total & 5 & 0.005063 & & & \\
\hline
\end{tabular}

Source: Field data 2021. 
Table 5. Drainage area and slope for road side gully initiation.

\begin{tabular}{ccccc}
\hline $\begin{array}{c}\text { Major } \\
\text { gullied areas }\end{array}$ & $\begin{array}{c}\text { Drainage areas } \\
\text { (ha) }\end{array}$ & $\begin{array}{c}\text { Slope } \\
(\mathrm{m} / \mathrm{m})\end{array}$ & $\begin{array}{c}\text { Gully } \\
\text { length }\end{array}$ & lithotype \\
\hline 1 (Kiangombe ) & 0.0017 & $0.47\left(27^{\circ}\right)$ & 1500 & Lithosols (sandy) \\
2 (Kathera ) & 0.013 & $0.45\left(7.2^{\circ}\right)$ & 800 & Combisols (51\% clay) \\
3 (Kerie) & 0.078 & $0.19\left(11^{\circ}\right)$ & 1000 & Combisols (51\% clay) \\
4 (Ngose) & 0.19 & $0.39\left(3^{\circ}\right)$ & 1340 & Arenosols (loam) \\
5 (Iriatune) & 0.097 & $0.019\left(4^{\circ}\right)$ & 1660 & Combisols (Clay $47 \%)$ \\
\hline
\end{tabular}

drainage area values are required for gullying in areas associated with roads.

\section{Conclusions}

The regression analysis indicated that slope and drainage area contributing to the gully, have statistically significant effects on the overall gully erosion in the study area. A region with increase slope $\left(>20^{\circ}\right)$ requires a limited contributing area for gully initiation, since higher terrain and ground roughness enhances channelization processes leading to closely spaced gullies and high frequency. Gentle slopes require a large area for gully initiation. Gentle slope areas $\left(<10^{\circ}\right)$ require a large drainage area for gully development, but generate larger volumes of overland flow with high erosive power, capable of creating large gullies. This creates features with deep, wide and widely spread characters. Other than drainage area and slope, other geomorphic factors play a significance role since they influence overland flow dynamics. Gullies on lower segment which occur on road sides resulting discharge from roads, requires lowers critical slope for a given drainage area for initiation. For such gullies, initiation starts only a few meters from the road, as influenced by the large volumes of water and force of acceleration from artificial created channels. Such artificially induced channelization points increase discharge, dictates for frequent and more elaborate planned structures for effective gully rehabilitation.

Prediction of threshold values remains an important parameter for determining points in a landscape a gully channel can start. Once critical slope and drainage areas necessary for gullying are recognized, an elaborated and effective strategy for gully rehabilitation can effectively be put in place for soil conservation. If the threshold values in a local slope are small, then, adopting farming methods that increase ground resistance helps to reduce further gully erosion. A large threshold value indicates considering more complex and well-designed conservation structures to increase resistance and reduce gully development.

\section{Acknowledgements}

The authors would like to acknowledge the European Union for sponsoring this study through the National Drought Management Authority under grant number NDMA/EDE DRMC/006/2019-2020. 


\section{Conflicts of Interest}

The authors declare that there is no conflict of interests regarding the publication of this paper.

\section{References}

[1] Katz, H., Daniels, J. and Ryan, S. (2013) Slope-Area Thresholds of Road-Induced Gully Erosion and Consequent Hillslope-Channel Interactions. Earth Surface Processes and Landforms, 39, 285-295. https://doi.org/10.1002/esp.3443

[2] Abdulfatai, A., Okunlola, A., Akande, G., Momoh, O. and Ibrahim, O. (2014) Review of Gully Erosion in Nigeria: Causes, Impacts and Possible Solutions. Journal of Geosciences and Geometrics, 3, 125-129.

[3] Jha, C. and Kapat, S. (2009) Rill and Gully Erosion Risk of Lateritic Terrain in South-Western Birbhum District, West Bengal, India. Revista Sociedade and Natureza, 21, 141-158. https://doi.org/10.1590/S1982-45132009000200010

[4] Marden, M., Betts, H., Arnord, G. and Hambling, R. (2008) Gully Erosion and Sediment Load: Waipaoa, Waiapu and Uawa Rivers, Eastern North Island, New Zealand. Sediment Dynamics in Changing Environments, Proceedings of a Symposium, Christchurch, December 2008, IAHS Publication 325, 339-350.

[5] Vandekerckhove, L., Poessen, J., Oostwoud, D., Nachtergaele, J., Kosmas, C., Roxo, M. and De Figueiredo, T. (2000) Threshold for Gully Initiation and Sedimentation in Mediterranean Europe. Earth Surface Landforms, 25, 1201-1220. https://doi.org/10.1002/1096-9837(200010)25:11<1201::AID-ESP131>3.0.CO;2-L

[6] Smith, R. and Bretherton, P. (1972) Stability and the Conservation of Mass in Drainage Basin Evolution. Water Resources Research, 8, 1506-1529.

https://doi.org/10.1029/WR008i006p01506

[7] Dong, X., Ding, S., Long, L., Deng, Y., Wang, Q., Wang, S. and Cai, C. (2016) Effects of Collapsing Gully Erosion on Soil Qualities of Farm Fields in the Hilly Granitic Region of South China. Journal of Integrative Agriculture, 15, 2873-2885. https://doi.org/10.1016/S2095-3119(16)61348-5

[8] Poesen, J., Nachtergaele, J., Verstraeten, G. and Valentin, C. (2003) Gully Erosion and Environmental Change: Importance and Research Needs. Catena, 50, 91-133. https://doi.org/10.1016/S0341-8162(02)00143-1

[9] Kirkby, J. and Bracken, J. (2009) Gully Processes and Gully Dynamics. Earth Surface Processes and Landforms, 34, 1841-1851. https://doi.org/10.1002/esp.1866

[10] Schumm, A. (1979) Geomorphic Thresholds: The Concept and Its Applications. Transactions of the Institute of British Geographers, 4, 485-515. https://doi.org/10.2307/622211

[11] Valentin, C., Poesen, J. and Yong, L.C. (2005) Gully Erosion: Impacts, Factors and Control. Catena, 63, 132-153. https://www.elsevier.com/locate/catena https://doi.org/10.1016/j.catena.2005.06.001

[12] Gómez Gutiérrez, Á., Schnabel, S. and LavadoContador, F. (2011) Procesos, factores consecuencias de la erosion por cárcavas; trabajosdesarrollados en la PenínsulaIbérica. Boletin de la Asociacion de Geografos Espanoles, 55, 59-80.

[13] Jain, V., Tandon, K. and Sinha, R. (2011) Application of Modern Geomorphic Concepts for Understanding the Spatio-Temporal Complexity of the Large Ganga River Dispersal System. Current Science, 103, 1300-1319.

[14] Frankl, A., Poesen, J., De Dapper, M., Deckers, J. and Nyssen, J. (2012) Gully Head 
Retreat Rates in the Semi-Arid Highlands of North Ethiopia. Geomorphology, 173-174, 185-195. https://doi.org/10.1016/j.geomorph.2012.06.011

[15] Istanbulluoglu, E., David, I., Tarboton, G., Robert, P. and Luce, C. (2003) A Sediment Transport Model for Incision of Gullies on Steep Topography. Water Resources Research, 39, 1103. https://doi.org/10.1029/2002WR001467

[16] Costa, L. and Bacellar, L. (2007) Analysis of the Influence of Gully Erosion in the Flow Pattern of Catchment Streams, Southeastern Brazil. Catena, 69, 230-238. https://doi.org/10.1016/j.catena.2006.05.007

[17] Dietrich, E., Dunne, T. and Brunege, J. (1978) Recent and Past Rates of Erosion in Semi-Arid Kenya. South-Eastern Latvia Landform Analysis, 17, 183-192.

[18] Bear, M. (1952) A Geological Reconnaissance of the Area S.E of Embu: Geological Survey of Kenya.

[19] Jaetzzold, R. and Schmidt, H. (1983) Farm Management Handbook of Kenya. Ministry of Agriculture and Livestock Enterprises, Kenya.

[20] Olson, M. (2004) Analysis of Land Use and Management Change on the Eastern Slopes of Mt. Kenya. Michigan State University, East Lansing.

[21] Ngugi, G., Leonard, E. and Muasya, M. (2011) The Contribution of Forest to Dryland Household Economy: A Case of Kiangombe Hill Forest, Kenya. Ethnobotany Research and Application, 9, 163-180. https://doi.org/10.17348/era.9.0.163-180

[22] GoK (2002) Government of Kenya Mbeere District Development Plan, 2002-2008. Government Printers, Nairobi.

[23] Vandaele, K., Poesen, J., Govers, G. and van Wesemael, B. (1996) Geomorphic Threshold Conditions for Ephemeral Gully Incision. Geomorphology, 16, 161-173. https://doi.org/10.1016/0169-555X(95)00141-Q

[24] Morgan, R. and Mngomezulu, D. (2003) Threshold Conditions for Initiation of Valley-Side Gullies in the Middle Veld of Swaziland. Catena, 50, 401-414. https://doi.org/10.1016/S0341-8162(02)00129-7 